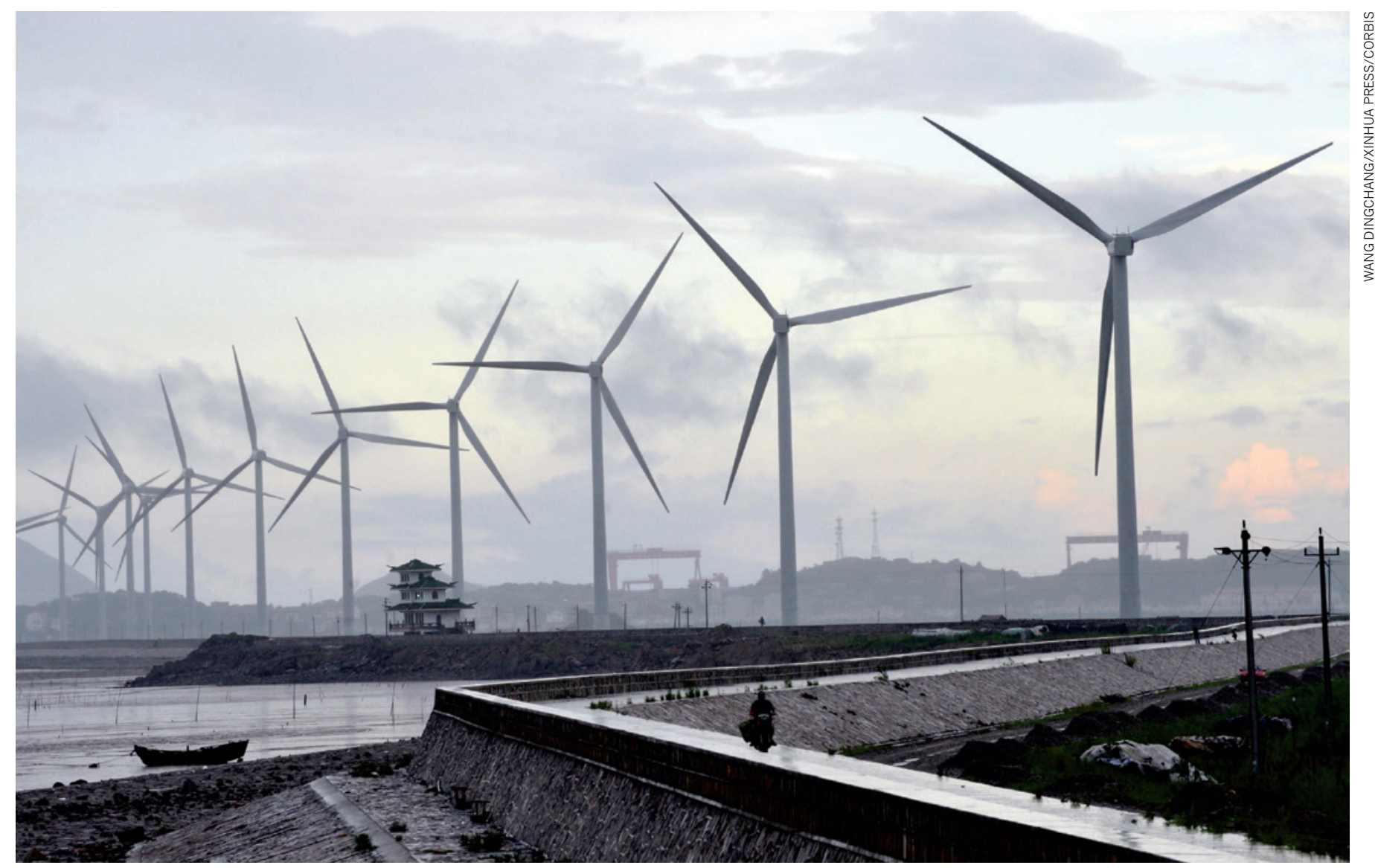

Some of China's most powerful wind turbines, at the Donghaitang wind farm in Wenling.

\title{
Manufacture renewables to build energy security
}

\section{Countries should follow China's lead and boost markets for water, wind and solar power technologies to drive down costs, say John A. Mathews and Hao Tan.}

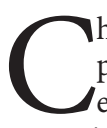

hina's rise to become the world's largest power producer and source of carbon emissions through burning coal is well recognized. But the nation's renewable-energy systems are expanding even faster than its fossil-fuel and nuclear power. China leads the world in the production and use of wind turbines, solar-photovoltaic cells and smartgrid technologies, generating almost as much water, wind and solar energy as all of France and Germany's power plants combined ${ }^{1}$. Production of solar cells in China has expanded 100-fold since 2005.

As the scale of Chinese manufacturing has grown, the costs of renewable-energy devices have plummeted ${ }^{2}$. Innovation has played a part ${ }^{3}$. But the main driver of cost reduction has been market expansion.
Germany and South Korea are following similar paths. In short: industrialization can go hand in hand with decarbonization.

Too many countries have yet to take notice. The United States and European Union are pursuing counterproductive policies, such as increasing trade tariffs on imported Chinese photovoltaic panels. Restricting global trade in renewable devices will only slow the rate at which costs decrease and will decelerate the world's retreat from fossil fuels.

As a result, uptake of renewable energies globally has been too sluggish to seriously reduce greenhouse gases and tackle climate change. For 15 years, countries have failed to deliver their carbon-reduction commitments under the Kyoto Protocol, hindered by the vested interests of the fossil-fuel industry and fears that the alternatives are costly.

The narrative around renewable energies needs to change. As in China, renewables must be seen as a source of energy security, not just of reduced carbon emissions. Today's discussions about energy security focus almost exclusively on maintaining access to fossil fuels. But unlike oil, coal and gas, the supplies of which are limited and subject to geopolitical tensions, renewableenergy devices can be built anywhere and implemented wherever there is sufficient water, wind and sun.

\section{GREEN GROWTH}

As the scale of manufacture and use of renewables rises, market forces will make them more accessible, affordable and 
efficient. Energy policies should therefore focus on promoting manufacturing, trade and competition in low-carbon technologies, rather than supporting ever more expensive, dangerous and inaccessible fossil fuels. Emissions reductions will follow.

China generates more than 5 trillion kilowatt-hours (kWh) of electricity, about 1 trillion kWh more than the United States. China's rapid economic expansion since it joined the World Trade Organization (WTO) in 2001 has been based on fossil fuels: it consumes around $23 \%$ of the world's coal production for electricity. But fossil fuels alone cannot power the industrial growth the country needs to keep up with the West.

Since the mid-2000s, China has also pursued a low-carbon energy strategy. Investment in hydroelectric, wind, solar and nuclear-power generating facilities increased by $40 \%$ between 2008 and 2012 from 138 billion renminbi (US $\$ 22$ billion) to about 200 billion renminbi. The share of investment in fossil-fuel power facilities in China, meanwhile, fell from around 50\% to $25 \%$ over the same period.

As a result, China's wind-power capacity has increased fivefold in the past four years (see 'Wind speed'). And in 2013, the generating capacity from new water, wind and solar sources exceeded ${ }^{4}$ that of new fossilfuel and nuclear facilities for the first time (see 'Renewables powerhouse'). Zerocarbon sources now contribute $9.6 \%$ of the energy used in China, up from $5.6 \%$ in 2000. This is a considerable achievement.

In 2013, China also hit its target - two years early - to generate almost $30 \%$ of electricity from renewables. The Chinese government aims for renewables capacity to reach 550 gigawatts (GW) by 2017 , or $48 \%$ above the 2013 level. No other country is investing so much money or generating so much renewable energy.

\section{ECONOMIES OF SCALE}

China is upgrading its power grid to accommodate power fluctuations and distributed generation for intermittent sources. In one demonstration project, the State Grid Corporation of China (SGCC) is investing 9.4 billion renminbi to integrate wind and solar-photovoltaic generation and storage devices into the main grid. The SGCC is helping to set international product standards for smart-grid elements that will underpin the export of these technologies to countries such as Brazil.

How has China's energy security improved? China became a net importer of oil in 1993, of natural gas in 2007, and of coal in 2011. Hitting its 2017 wind, water and solar power targets, we calculate, would translate into a saving of $45 \%$ on current imports of oil, coal and natural gas.

There are two keys to China's success in renewables. Focused policies drive

\section{WIND SPEED}

Wind-power capacity has risen fivefold in China in the past four years. Turbine costs fell as the scale of manufacturing rose.

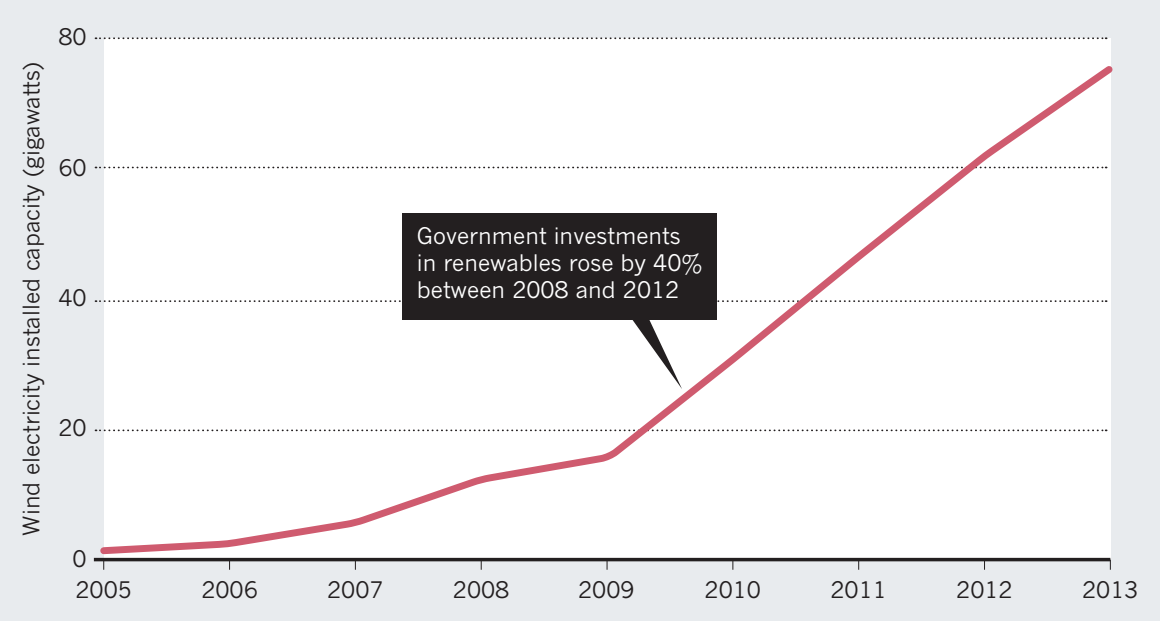

investment in selected sectors and encourage domestic take-up by measures such as feedin tariffs. And industrial dynamics, including economies of scale and efficiencies gained through learning, drive down unit costs as the global market expands.

Renewable-energy generation requires the manufacture of many components, such as wind turbines, solar-photovoltaic cells, mirrors, lenses, batteries and energystorage systems. From 2010 to 2013, while total global photovoltaic installation more than tripled from $40 \mathrm{GW}$ to $140 \mathrm{GW}$, China's installation expanded 22 -fold, from $0.8 \mathrm{GW}$ to $18 \mathrm{GW}$. Supplying the international market, as well as the domestic one, has helped to drive down costs of photovoltaic panels by $80 \%$ since 2008 . Solar-power users around the world have benefited from lower prices.

"No other
country is
investing
somuch or
generating
somuch
renewable
energy."
A few other countries are following a similar strategy. South Korea, for example, is committed to 'green growth' - expanding its smart grid and focusing its production on emerging clean sectors such as zero-emission vehicles. And Germany has been expanding its manufacture and use of solar and wind power (under its Energiewende energy-transition programme) since the early 2000 s, with the aim of replacing its nuclear power with renewables.

The same principle of industrial-scale production established US supremacy in the automotive industry a century ago. Between 1909 and 1916, Henry Ford reduced the cost of his Ford Model T by $62 \%$, from $\$ 950$ to $\$ 360$. Each year, sales doubled - from fewer than 6,000 in 1908 to more than 800,000 in 1917.

Yet US energy policy emphasizes exploiting domestic coal seam gas and shale oil, through innovations such as hydraulic fracture (fracking) and horizontal drilling. The problems of diminishing returns and environmental costs of fossil fuels remain ${ }^{5}$. The United Kingdom, too, is inclined to build up its supplies of coal seam gas by fracking, and to expand its fleet of nuclear reactors, a portfolio approach that will leave the country importing others' technology.

\section{CHANGING THE CONVERSATION}

Reframing the emissions debate in terms of energy security has profound implications for international negotiations under the terms of the United Nations Framework Convention on Climate Change. In December, national representatives will gather in Lima for the preparatory meeting to the Paris conference in 2015. Their agenda remains negotiating voluntary national carbon-emissions reductions, rather than promoting renewable-energy industries, as the fastest route to decarbonization.

But governments that build strong renewables sectors can achieve those emissions reductions while enhancing their energy security and building their manufacturing industries. Another advantage of the market-oriented approach is that renewables are not burdened with the task of resolving the entire climate-change problem. Few countries will be able to rely on water, wind and solar power alone, and some fossil fuels will continue to be used.

Our critics will counter that technologybased solutions raise concerns over the availability of industrial materials and land for building solar and wind devices and farms. But our calculations suggest ${ }^{6}$ that a global renewables push for an extra 10 terawatts of power-generation capacity could be achieved on current industrial scales over the next 20 years, by which time the world energy 


\section{RENEWABLES POWERHOUSE}

In 2013, China led the world in renewable-energy production, mainly from hydroelectric and wind power.

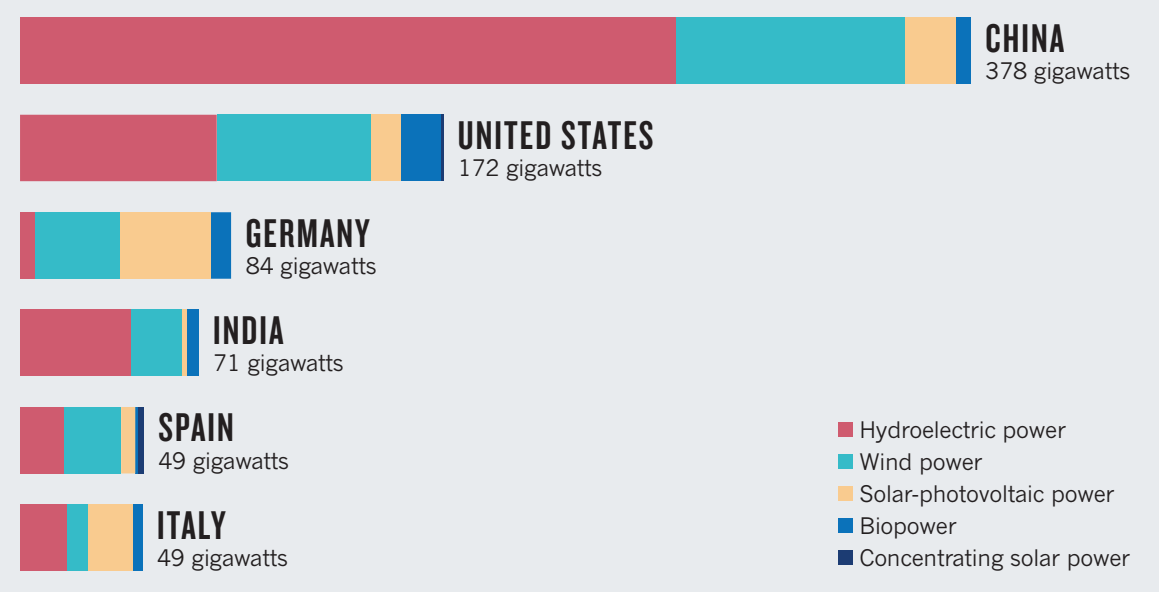

system would be well on the way to total conversion. Producing the extra 10 terawatts from renewables needed to transform global electric power would require more than 5 million square kilometres (about twice the size of Kazakhstan) filled with around 3 million wind turbines, 14,000 concentrated solar-power installations and 12,500 solar-photovoltaic farms. These technologies could perhaps be accommodated in the world's desert and semi-desert regions. The targets are large - but they are manageable compared with current world production levels of 1.75 billion mobile phones per year or 84 million vehicles per year ${ }^{6}$.

\section{TRADE SOLUTIONS}

The main obstacles to expanding renewables uptake are failed policies and continuing subsidization of fossil fuels.

All governments should enlarge the market for renewable power by encouraging manufacture and trade of devices. Countries should foster export and import of renewable electric power (from, say, North Africa to Europe under the DESERTEC project, or from Mongolia to China, Japan and South Korea
"These technologies could perhaps be accommodated in the world's desert and semi-desert regions." under the east Asian super-grid proposal). Above all, the narrow agenda that the Kyoto process has enforced needs to be broadened.

How? One way involves expanding free trade in renewable devices. Here, the WTO could complement the Kyoto process ${ }^{7}$. A preliminary agreement to free up trade in renewables was adopted by Asia-Pacific Economic Cooperation countries in 2012, and could be proposed to the WTO. A precedent exists with trade in personal computers and other information-technology products. It was expanded from a voluntary agreement to reduce tariffs, signed up to by most major industrial countries, and adopted by the WTO in 1997.

Private finance must also play a part. The Kyoto-process negotiators have so far considered that financing for climate-related initiatives should come from tax-based public finance rather than from private or even government-backed development banks. This emphasis needs to change. Green bonds lower the costs of capital and facilitate the scaling up of investments. One example is the $\$ 500$-million bond issued by the Export-Import Bank of Korea last year allocated exclusively to finance green projects around the world.

China is leading the way. By placing the emphasis on production scale and market growth, it is contributing more than any other country to a climate-change solution. Its build-up of renewable-energy systems at serious scale is driving cost reductions that will make water, wind and solar power accessible to all.

John A. Mathews is professor of strategic management at Macquarie Graduate School of Management, Macquarie University, Sydney, Australia. Hao Tan is senior lecturer at Newcastle Business School, University of Newcastle, Callaghan, Australia. e-mail:john.mathews@mgsm.edu.au

1. BP. BP Statistical Review of World Energy 2014 63rd edn. (BP, 2014).

2. World Energy Council World Energy Perspective: Cost of Energy Technologies (World Energy Council, 2013).

3. Trancik, J. E. Nature 507, 300-302 (2014).

4. Mathews, J. A. \& Tan, H. Asia Pac. J. 12, (2014); available at http://go.nature.com/z6job5.

5. Mathews, J. A. \& Reinert, E. Futures $61,13-22$ (2014).

6. Mathews, J. A. \& Tan, H. J. Sustain. Energy Eng. http://dx.doi.org/10.7569/JSEE.2014.629505 (2014).

7. Helm, D. Nature 491, 663-665 (2012). 